formed a plaster on the walls, its thickness being at most three inches. It showed prismatic structure, though rather small. The air within was cold (I had no thermometer); but as the surface of the ice was wet, it was above $32^{\circ} \mathrm{F}$., though I think not much. The guide told me that the fissures in winter-time were filled with snow. This accumulation, probably owing to the shape of the fissure, no longer remained as snow, but was represented by the ice on the floor and walls, which the guide said seldom, if ever, disappeared. The absence of ice from the walls of the Ingleborough "swallow hole" was probably due to some exceptional dryness of the rock ; but Prof. Hughes has undoubtedly found a "baby" ice-cave, like that I have described, and it will be worth examining some more of these dry shafts to see whether a slightly better developed specimen may not be lurking in the neighbourhood.

T. G. BONNEY.

\section{Permeability of Iron under the influence of the Oscillatory Discharge from a Condenser.}

In your issue of August 2 there is an abstract of a very interesting paper, read by Prof. Trowbridge, on his experiments with a battery of 20,000 secondary cells. In it he mentions that the permeability of iron when under the influence of a very powerful discharge from a large condenser is now under observation.

I should like to draw attention to some experiments I was making over a year ago in Lord Blythswood's laboratory (an account of which has not yet been published), in which I have gone into the subject in some detail.

In my experiments the lowest frequency used was about 5000 a second. I enclose two photographs of sparks taken in

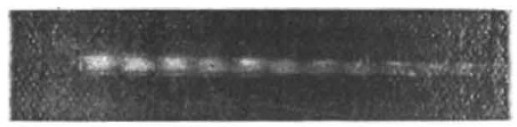

FIG. I.

the usual way with a revolving mirror. The discharge in photograph (I) took place through a coil of about 5 millihenrys selfinduction from a battery of Leyden jars of a total capacity of -06 microfarads, the potential difference between the coatings, before discharge, being 13,500 volts. In photograph (2) a fine wire core, consisting of 550 No. 28 soft iron wires, was inserted

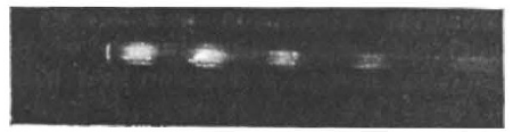

FIG. 2.

into the coil (which was wound on a hollow paper spindle of about $\mathrm{I} \cdot 3 \mathrm{~cm}$. internal diameter). The other conditions of discharge were identical in the two cases; the speed of the mirror, however, was I9 revolutions per second for photograph $(t)$, and 16 per second for photograph (2), thus tending to draw out the spark more in the first photograph.

The essential differences are, however, well marked. At the beginning of the discharge we have the "pilot" spark, first noticed by Prof. Boys; and then in the photograph (2), taken with the iron wire cores, a series of oscillations gradually in creasing in length. The first half-oscillation, however, is nearly twice as long as the half-oscillations in photograph ( $\mathrm{I}$ ), when there were no iron wire cores in the coil. The increase in the time for a half-oscillation is due, of course, to the increased selfinduction of the coil on account of the iron; and the graduallyincreasing length is due to the increase in permeability of the iron as the intensity of the discharge dies away. In photograph (I) the frequency of oscillation of the spark taken with the coil having air cores is about 9000 per second, and in (2) the approximate magnitude of the current during the first discharge with the iron cores, 15 amperes.

It would be impossible in the course of a short note to describe in detail the work that has been done, but in numerous experiments (over three hundred spark photographs have been taken) that have been made, the iron has been found to behave in the same way under these oscillating magnetisations as it does when steady currents are used to produce magnetising forces of the same intensity. In most experiments single layer coils have been used in which the magnetising forces due to a given current can be calculated, and it has been possible to determine approximately the forces acting on the iron. From the results, curves showing the variation in permeability with magnetising force have been plotted. In some experiments, the magnetising current due to the discharge has been as large as 1000 amperes. In order to obtain discharges as powerful as this, a very large glass-condenser has been used with a total capacity of I' 5 microfarads, made up of plates of glass (coated with shellac) $\mathrm{I} \cdot 6 \mathrm{~mm}$. $\left(\mathrm{I} / \mathrm{I} 6^{\prime \prime}\right)$ thick. The conducting surfaces are of tinfoil. The glass appears a great deal stronger than that used by.Prof. Trowbridge, as it has been tested repeatedly at 20,000 volts. It is possible, however, that the suddenness with which his condenser is charged from his cells may account for the readiness with which the glass breaks. In my experiments the condenser was charged by a large Wimshurst machine of 160 plates, which took almost half a minute to get up the full potential of 20,000 volts. The glass used is known technically as $15 \mathrm{oz}$. 3rds selected flat sheet, and was obtained from Messrs. Malloch, of Glasgow.

Blythswood Laboratory, Renfrew, August 7 .

\section{Function of the Whips of the Larva of the Puss Moth.}

YouR correspondent (p. 389) will find a detailed account of the various defensive appliances of the larva of Cerura vinula in Prof. Poulton's work on the "Colours of Animals" (International Science Series), and in papers published by him in the Transactions of the Entomological Society of London for 1886 and 1887 , the latter papers being illustrated by beautiful coloured plates.

It is usually believed by entomologists that the function of the "whips" in the caudal appendages of the larva is to drive away, or frighten away, Ichneumon Flies or other enemies, but there is still room for further inquiry ; and although the larva is highly protected, it is liable to the attacks of some species of Ichneumon Flies, though it may be able to defend itself against others, for the protection of no animal is absolutely complete.

The appendages are doubtless homologous with the retractile fleshy fork in the neck of the larve of the Swallow-tailed Butterflies (Papilionidre), which probably fulfils a similar function.

Hilden, Sutton Court Koad, Chiswick.

The Migration of Swifts.

ON the morning of Friday, August IO, I witnessed a large flight of Swifts travelling westward along the Sussex coast. The birds were passing this place in a continuous though thin stream for several hours; I saw them myself from $10 \mathrm{a} . \mathrm{m}$. when I first visited the shore, and watched them till 12 noon. A few birds were also noted travelling in the same direction between 5 p.m. and $6 \mathrm{p} . \mathrm{m}$. The day was bright but showery, and a fresh W.N.W. breeze was blowing at the time, so that the birds were flying almost against the wind; they flew low, seldom rising fifteen feet in the air, and often passing within two feet of my head as I lay on the shingle; they kept to the coast-line and for the most part over the top of the fringe of tamarisks that here stretch for miles just above the shingle. Since that day I have not seen a single Swift in the neighbourbood, in spite of having travelled on my bicycle as far west as the mouth of Chichester Harbour along the coast, and to various places north of this line as far as Chichester and Arundel inland. It would be interesting to know if other observers witnessed any similar flights on August 10, and also if Swifts are still to be seen in any places in our islands at the present time. I have on two previous occasions seen Swifts arrive on the east coast of Norfolk as late as the first week in September (after a complete dearth of the birds for some three weeks), and depart again after a few days' sojourn-these perhaps are migrants from the European continent. As many of your readers are now doubtless at the seaside, it seems a favourable opportunity to ask them to keep their eyes open and record any facts that they may observe bearing on the movements of these birds.

East Preston, near Worthing, August 19. 